\title{
THE STUDY OF GROWTH FACTORS OF THE PROFIT ORIENTED BUSINESS IN THE CONSTRUCTION INDUSTRY \\ Sergey Oparin ${ }^{1}$, Nikolay Chepachenko ${ }^{2}$, Marina Yudenko ${ }^{3}$, Irina Kuzovleva $^{4}$
}

\begin{abstract}
This study concluded that the problems of economic growth are determined by a number of factors, the main of which are-economic, industrial, technological, institutional, non-economic. The article focuses on the analysis of institutional factors which regulate companies' activities by reducing the impact of administrative barriers. This article identifies the role of economic efficiency and its influence on the economic growth of the construction industry businesses. This article offers a method of profit calculation by the reduction of transaction costs. This method is adapted to the construction sector, which features a number of independent and related fields, a large number of participants of the construction process and institutions that altogether lead to the occurrence of administrative barriers. The calculations that were done confirm that the reduction of transaction costs affects the efficiency of construction companies. The resulting extra profit, from reducing the transaction costs, is a source of economic growth for companies in the construction industry.
\end{abstract}

JEL Classification Numbers: O12, O43, M21, K21; DOI: http://dx.doi.org/10.12955/cbup.v6.1183

Keywords: institutional factors, economic growth, construction, entrepreneurship, economic efficiency, administrative barriers

\section{Introduction}

The relevance of the topic is confirmed by the fact that a significant number of scientific studies have been focused on problems of economic growth. This is due to the fact that the trend of economic growth is the dominant trend in the development of economic systems and it is multidimensional, as it covers research of the interactions between economic growth and crisis, economic growth and efficiency, economic growth and governance, economic growth and technology.

The issues of theory and methodology of companies' economic growth and their performance is currently the subject of research by both foreign and Russian scientists. Scientists of different epochs such as Sukharev (2015) and Yanzhul (1912) considered the importance of the study of non-economic factors of economic growth (honesty in trade and industrial relations). Ivanov (2015) notes that imbalance between the growth of labor productivity and wages causes a necessity of the analysis of the impact on the companies' economic growth. Postolov et al. (2017) believe that the introduction of new forms of business behavior affects the efficiency and growth of companies.

According to Oparin et al. (2017), the influence of institutional factors have a sufficient impact on companies' economic growth.

A number of economic theories consider a fact that upon solving the problem of meeting human needs, costs arise not only due to the involvement of the production factors (transformation costs) into the production process but also as a result of interaction between subjects of economic activity (transaction costs). They are not associated directly with the process of the material values creation, but, nevertheless, influence the magnitude of economic benefits. Transaction costs are determined by a number of factors, including administrative barriers, ensuring the legalization of corruption flows and monopolization of markets through administrative resources.

The analysis of institutions and institutional changes is adequately covered in the works of Nobel Prize winners Ronald Coase (1995), Douglass North (1997), and Oliver Williamson (1996). However, the issue of the impact of institutional factors on economic growth and the effectiveness of institutions remains insufficiently developed in the scientific literature.

\section{Review of the literature}

Studies of economic growth have been undertaken in the 60-ies. At that time the economists discovered the "residual factor" of economic growth (Griliches, 2004, p. 122). The conclusion of the research is as

\footnotetext{
${ }^{1}$ Chair of Economics and management in the construction Petersburg State Transport University Emperor Alexander I, Saint-Petersburg, Russia, oparinsg@mail.ru

${ }^{2}$ Department of Economics and management in construction Petersburg State Transport University Emperor Alexander I, Saint-Petersburg, Russia, nvchepachenko@mail.ru

${ }^{3}$ Department of Economics and management in construction Petersburg StateTransport University Emperor Alexander I, Saint-Petersburg, Russia, mnuspb@mail.ru

${ }^{4}$ Department of Economics and management Bryansk state engineering- technological University, Bryansk, Russia, ikuzovleva@yandex.ru
} 
follows: the observed growth of the goods output in a small degree can be attributed to the increase in traditional resources. It should be noted that a number of modern scholars of economic growth explain this by the increase of costs. Scientists John Kendrick and Solomon Fabricant (1954) noticed intercommunication of the "residual factor" of economic growth and technological progress and increasing production efficiency. They have turned the "residual factor" into an intellectual asset, the method of measurement of scientific and technological progress.

The authors of the above article consider economic growth of companies as quantitative increase in the goods output as a result of increasing the production, economic, institutional and other capacities that determine the increase of efficiency of use of resources, their optimal combination and the market share increase.

In economic literature, the economic efficiency of the entities' activity is barely mentioned in the context of its institutional support. Usually they write about economic growth and socio-economic development. Exploring the issues of efficiency, we focus on economic activity such as the construction industry. 235 thousand construction companies operated on the Russian market in 2016. The trend of decline in construction production which began in 2014, was observed in 2015 and continued in 2016. The amount of work performed by the construction companies of all forms of ownership in 2016 counted for 6184 billion Rubles, which was $4.3 \%$ (Finance of Russia, 2017) less than the amount in 2015. Thus the question of economic growth and efficient operation of companies is relevant in the field of construction.

By far the economic literature has a clear idea about the essence of efficiency. There is a detailed classification of the characteristics and criteria of efficiency. However, the proposed efficiency indicators often confuse notions of outcome and impact, effectiveness, efficiency and intensity, efficiency and productivity. Often, in the works, efficiency is correlated with the companies' success.

The concept of Novozhilov (1995) according to which economic efficiency is defined as the ratio of the effect to the cost required to such effect production, is the most well-grounded in Russian economic science.

Asaul (2001) believes that efficiency is a qualitative category that is associated with the intensity of business development. It reflects the underlying processes of improvement that takes place in all its elements, and avoids mechanistic approaches. Such a broad interpretation does not contradict with the effectiveness of its understanding and at the same time does not contradict with many approaches to the interpretation of this concept. One of which is the consideration of the impact of institutions on the construction companies' activities through transaction costs in the calculation of their efficiency.

In turn, Sukharev (2015, p. 124) concludes that the economic science has developed a false idea that development can be effective when it is provided at the lowest cost. A problem of search of extremum arises, to define what the minimum cost is. But development is all about creating new material items and as a consequence "economic growth is characterized by a general increase of costs". The author rightfully believes that in the analysis of economic growth, we should talk about this measure as an efficiency indicator, calculated through the "ratio of the new product (income) to the value of the national wealth (similar to the elements of national wealth: physical capital, natural resources, human potential) as an indicator of overall performance.

Sharing the opinion of Sotnikova (2008, p. 169) we believe that the scientific economic literature draws sufficient attention to the assessment of the production subsystem performance of a company's infrastructure however, the types of transaction infrastructure and the issues of its evaluation are not fully considered. The author considers it expedient to allocate the criteria of an estimation of efficiency of the institutional subsystems in the composition of the transaction infrastructure. The author proposes to refer licensing, customs legislation, taxes and fees, standardization and quality insurance system costs, security system and international law to the cost indicators. The author proposes to refer gross and net income, performance indicators, institutional infrastructure, the profitability of sales and labor productivity to the result indicators. It should be noted that the listing cost indicators, the author, in our opinion, has not allocated all of the costs that the entity faces in its activities. At the same time she unjustifiably attributes the taxes to the element of the institutional infrastructure. The costs specified by the enterprises are included in the costs or profit and are not classified as transactions.

In scientific literature the definition of efficiency is different from the classical approach. For example Nickolaeva and Belova (2014) have identified and explored the factors and indicators of success in 
medium-sized businesses, considering that success is a multidimensional and partially subjective concept, which implies, depending on the context, effectiveness, sustainability, performance, and the ability of the company to achieve its goals.

\section{Methodical approaches to definition of the enterprises' economic efficiency}

The author of this article believes that the effectiveness of companies determines their economic growth at the expense of profit growth and offers a classic approach to the definition of efficiency that takes into account increased transaction costs.

In economic practice, enterprises' efficiency is often characterized by the indicator of profitability of the sold goods, products (works and services).

The profitability $(\mathrm{P})$ of the sold goods, products (works and services) is calculated using the following formula:

$$
P=\frac{B F R}{C v} \times 100 \%
$$

where $B F R$ is the balanced financial result (profit minus loss) from the sale of goods, products, works and services;

$C v$ is a cost value of sold goods, products, works and services.

The balanced financial result is the final financial result calculated on the basis of accounting of the all economic operations of the company. The profitability of the companies is not a new indicator and is calculated by the statistical authorities of the country, the regions and by enterprises and companies themselves.

In the article, the enterprise's effectiveness $(E E)$ is to be calculated according to the following formula:

$$
E E=\frac{B F R+\triangle E P}{C v} \times 100
$$

where $\triangle E P$ is an extra profit resultant from saving transaction costs.

That is the indicator of transaction costs which shows the influence of existing institutions on the efficiency of the construction industry companies. The initial data for the calculations and calculation results is displayed in Table. 1.

\section{Research results}

All the indicators needed for the calculation of the performance indicator can be easily found on the official website of the Rosstat of the Russian Federation, except one indicator - the transaction costs. It remains undecided how to define transaction costs. This issue has always been a subject of discussion (Eggertsson, 1990; Demsetz 1969). We refer to the materials of The huge demand for small business, the second Russian forum of small and medium business (June 2016), where two main reasons for restricting the development of small and medium business have been emphasized: a) administrative barriers ensuring the legalization of the corruption flows; b) monopolization of markets through the administrative resources. The costs of small business entrepreneurs upon the indicated problems are transactional in nature and are caused by institutions (formal rules, laws) inefficiency. At a panel discussion of the forum called Reducing administrative barriers for doing business June 2015, it was announced that the cost of administrative barriers constitutes $7 \%$ of the gross domestic product of companies and enterprises per year (5628 billion Rubles, or $\$ 94$ billion). This is a huge figure.

It is important to note that administrative barriers are the problem of small businesses not only in Russia but also in other countries of the world. Scientists from Kosovo (Hoxha et al., 2016) note that the barriers affect the performance of small business and business management.

On the basis of the empirical data in the field of construction the calculations that show a strong impact of administrative barriers on the effectiveness of companies have been made and the scientists have come to the conclusion that the reduction of transaction costs will provide additional profit and direct it to the companies' economic growth. 
Considering that the amount of work performed by the construction industry in 2016 amounted for 6184 billion Rubles, provided that the cost of business on overcoming the administrative barriers accounted for about 7\%, they will result in 432 billion Rubles ( $\$ 7$ billion) saved. In 2015 upon the amount of work of 6148 billion Rubles, the costs of business on overcoming of administrative barriers amounted to 430 billion Rubles ( $\$ 7.6$ billion) in 2014, upon the amount of work of 6125 billion Rubles, the expenses amounted to 429 billion Rubles (\$11 billion). For the other years, calculations were performed in a similar way.

Analysis of the data presented in Table 1, clearly shows that the financial activity of the construction industry companies in 2014 and 2015 had negative results. But due to additional profit from saving transaction costs, the situation is changing and construction is becoming an effective business field. Of course, when calculating the size of transaction costs, not taking into account all the components, even the performance costs associated with administrative barriers have a significant impact on the effectiveness of companies and their economic growth.

\begin{tabular}{|l|c|c|c|c|c|c|c|}
\hline \multicolumn{7}{|c|}{ Table 1: input data to the calculation of the efficiency of construction businesses } \\
\hline \multicolumn{1}{|c|}{ Indicators } & $\mathbf{2 0 1 1}$ & $\mathbf{2 0 1 2}$ & $\mathbf{2 0 1 3}$ & $\mathbf{2 0 1 4}$ & $\mathbf{2 0 1 5}$ & $\mathbf{2 0 1 6}$ \\
\hline The balanced financial result (BFR), billion Rubles & 107 & 176 & 601 & -75 & -54 & 131 \\
\hline $\begin{array}{l}\text { Transaction costs in the construction industry } \\
\text { (including for overcoming the administrative } \\
\text { barriers) (EP), billion Rubles }\end{array}$ & 359 & 400 & 421 & 429 & 430 & 432 \\
\hline $\begin{array}{l}\text { Cost value of sold products, (works and services), } \\
\text { billion Rubles }\end{array}$ & 4896 & 4896 & $\begin{array}{c}1044 \\
83\end{array}$ & 5425 & 5312 & 5390 \\
\hline $\begin{array}{l}\text { The effectiveness of construction industry } \\
\text { companies without taking into account transaction } \\
\text { costs, \% }\end{array}$ & 2,2 & 3,6 & 5,8 & - & - & 2,4 \\
\hline $\begin{array}{l}\text { The effectiveness of construction industry } \\
\text { companies taking into account the additional } \\
\text { profit from saving transaction costs, } \%\end{array}$ & 9,5 & 11,7 & 9,8 & 6,5 & 7,1 & 10,4 \\
\hline $\begin{array}{l}\text { Source: Finance of Russia. 2016. Statistical compendium } \\
\text { Author's calculations }\end{array}$ & & & & & \\
\hline
\end{tabular}

Analysis of the data in the Table 1 shows that in 2016 due to saving on transaction costs, the efficiency of construction industry companies increased from $2.4 \%$ to $10.4 \%$, and the businesses received an additional profit of $\$ 432$ billion Rubles or $\$ 7$ billion.

\section{Conclusion}

The results of the calculations show significantly higher values of efficiency resultant from the additional profit from saving transaction costs. Thus, due to institutional factors that reduce transaction costs, companies can find additional reserves for profit growth, reproductive processes, growth in the prosperity of the businesses and the satisfaction of consumers. It is possible to reduce transaction costs and get additional profit by means of effective institutional infrastructures and its social institutions. In this regard, it is necessary to focus on the effectiveness of the business activities' regulations.

It has been proved that the institutional factors not only lead to higher economic efficiency, but to economic development of the companies at the expense of profit growth and contribute.

\section{References}

Asaul, A. N. (2001) The phenomenon of investment-construction industry or construction industry in a market Economics is being saved: monograph [Webblogpost]. Retrieved March 22, 2017, from: http://www.aup.ru/books/m65/.

Demsetz, Harold (1969). Information and Efficiency: Another Viewpoint. Journal of Law and Economics 12, 122.

Eggertsson T. (1990) Economic behavior and institutions. Cambridge University Press.

Griliches Z. (2004) Productivity, technological progress and limitations of the data. Origins. Moscow: Higher School of Economics Publishing house, 122-165.

Ivanov, O. P. (2015) The mismatch of growth of productivity and wages: possible economic and social consequences. Society and power. 5, 111-116. 
Kiril Postolov, Maria Magdinceva Sopova, Lidija Pulevska Ivanovska, Tanja Angelkova Petkova \& Saso Josimovski (2016). Modern entrepreneurship as a factor for success in the operation of tourism enterprises Innovations in science and education Central Bohemia University. CBU International Conference Proceedings. $1-5$.

Nickolaeva, E. V., Belova, I. A. (2014).Transaction costs and the tax burden as factors of success of the average business in Chelyabinsk region. Business strategies. 4(6), 2-9.

Novozhilov, V. V. (1995). At the origins of a genuine economic science. Moscow: Science. 233.

Douglas North (1997). Institutions, institutional change and economic performance. Moscow: the Nachala, Foundation of economic books ,197.

Rifat Hoxha, Hoti Hamdi \& Remzi Ahmeti (2016). Management perspective and development of small and medium enterprises in Kosovo - Innovations in science and education Central Bohemia University. CBU International Conference Proceedings, 235-239.

Coase, Ronald (1995). The nature of the firm. Theory of the firm. Saint-Petersburg: Economic school. 534. (Original work published 1937).

Sergey Oparin, Nikolay Chepachenko \& Yudenko Marina (2017).The role of social institutions in the activity of entrepreneurs in the construction sector - Innovations in science and education Central Bohemia University. CBU International Conference Proceedings. 337-342.

Sotnikova, O. G. (2008). Assessment of efficiency of the enterprise infrastructure functioning. Bulletin of the Volga state University. 1(12). 165-170.

Sukharev, O. S. (2015) Economic growth, institutions and technologies. Moscow: Finance and statistics. 464 .

Williamson O. I. (1996). The economic institutions of capitalism: firms, markets, "relational" contracting. SPb.: Lenizdat; CEVPress. 702.

Fabricant S. (1954). Economic progress and economic change. National bureau of economic review. 34th Annual Report. NewYork: NBER. 97.

Yudenko, M. N., Leontiev A. A. (2017). Institutional issues of small business in construction sphere. Economics of construction. 1. 15-23.

Yanzhul, I. I. (1912). The economic importance of honesty. Journal of education. 4. 27.

Finance of Russia. 2016. The statistical compilation. Moscow: Rosstat. 2016. 343. 